\title{
World Englishes in world religions
}

\author{
DANIEL R. DAVIS*
}

In the beginning was the Word. Often quoted, these opening words from the Gospel according to John nonetheless show that the relationship between language and religion goes beyond intimacy to identity. Whether this is taken as a specific moment in the theorization of one religion, the culmination of a particular line of thinking, or a more general truth about how humans grasp the essence of their existence, it is clear that language and religion depend on one another in both immediate and profound ways. To put it another way, linguists, philosophers, and theologians have a lot to talk about. How does language mediate our conception of the world, of what is true or essential? Is language a reliable guide to the world? How does it underpin belief? How does it enable a community to constitute itself in terms of shared beliefs? What do these beliefs require of language, and what does language require of these beliefs? Even the terms by which I frame these simple questions have been debated for centuries, and one hesitates to rush into the debate. Yet it is possible to say that, various religious and philosophical traditions have evolved according to particular views of language. Language needs to adopt particular forms and to be used in particular ways in order to serve the needs of individual religions. Sociolinguists will be interested in how language variation aligns with religion. How does the use of a language in a religious context bring about change in the language? How does it reveal or make use of language variation? What are the properties of religion as a sociolinguistic domain? What language ideologies do participants adhere to?

In the course of its self-definition as a field of study, linguistics and even sociolinguistics may have for the most part left the domain of religion to the anthropologists, philosophers, and theologians. The obvious exception is the Sapir-Whorf hypothesis, but the reception of this idea has been contentious within the field. It may be that religious language is seen as the prototype for highly standardized, writing-centred, and prescriptive language use, and would not appear to be a fruitful field for new approaches interested in the primacy of speech, and variation within the community. The growth of linguistics within the academic world came at a time when traditional religions were undergoing extensive restructuring and even decline in many English-speaking societies, especially in the Inner Circle. However, as sociolinguistics developed, attention was bound to come round to religion among other social domains.

Within the field of world Englishes specifically, the Kachruvian conceptualization created a space for new ways of thinking about English as a world language. Understanding how English is nativized, or adapted by speakers to the uses and needs of immediate contexts across the globe, involves culture as part of those contexts. Culture, in turn, often

\footnotetext{
*Department of Language, Culture, and Communication; University of Michigan-Dearborn, Dearborn, MI 48128-2406, USA. E-mail: davisdr@umich.edu
} 
involves religion or other belief systems. Ultimately, the demands that a religion places on language shape how members of a culture see their language. As Firth says, 'The notions men have about language derive from their particular type of society and cultural inheritance, and especially from their religion.' (Firth 1937, cited in Crystal 1965:10). Against this view, Crystal (1965:10) argues that, 'religion can learn much more from the scientific study of language than language ever learned from it', and then devotes most of the book to an introduction to modern linguistics. He gives a set of guiding principles for a liturgical language (1965:151-5), based on characteristics including formality of style and a register involving archaism, formulaic utterances, and specialized vocabulary.

Ferguson (1982) recognizes a link between the spread of religion and the spread of language, and this is cited by Fishman and Omoniyi (2006) as they strike a balance between linguistic and sociological approaches and their relative contribution to our understanding of the relationship between language and religion. This work draws together a collection of papers on the sociology of language and religion. Two of these are contributed by authors featured in this symposium (Chew and Pandharipande), and others (Kamwangamalu, Omoniyi, and Wolf) deal with societies in which English constitutes a factor in questions of language and religion. A number of the papers explore the role of languages in establishing identity, notably Joseph's (2006). The focus is broad and the emphasis of these papers is on the whole on languages other than English, though English plays a part in the dynamic of language choices in religious contexts, or, alternatively, within the wider context of those societies discussed. Omoniyi (2010) and his contributors refine this focus to examine change, conflict, and accommodation.

Each of the five papers gathered in this present symposium on world Englishes in world religions employs a different methodology to investigate a particular function of the English language with respect to religion. Phyllis Ghim-Lian Chew examines the use of Singlish by teachers in Islamic studies classrooms in Singapore. Singlish is shown to be an essential part of the learning process, a means of scaffolding the material covered, lessening distance between teacher and student, and softening the impact of the use of English in a context characterized by the use of Arabic and Malay. Mohammad Khalil compares two different English translations of the Qur'an, showing how translators' choices have important theological consequences in how Muslims understand the fate of non-Muslims. Jean-Paul Kouega and Claire-Solange Emaleu look at the structure of the Roman Catholic mass, and map out the language choices adopted for each section in the multilingual context of southwest Cameroon. They find that English and Pidgin English, and especially the two of these used in alternation, figure prominently in the six languages appearing in the mass, and that this choice is determined by the language background of the priest, their intelligibility to the congregation, the availability of liturgy and other religious materials, and the leadership of the choir in selecting music. Rajeshwari Pandharipande explores the use of English in Hindu ceremonies in the United States, and develops a di-system model to explain how the use of a new language in a religious context results in a new semantic system (and by extension, semantic diglossia) for that language. This nuanced theorization enables her to consider the tension between the roles of Sanskrit and English in the Hindu diaspora in the United States. Winifred Whelan traces the fate of the English translation of the Roman Catholic liturgy during the latter third of the twentieth century, in which the English translation of the liturgy became subject to a conservative and literalist ideology of translation. Views on the significance and utility of the translation change according to larger sociopolitical movements within the church. 
What emerges in light of this symposium is a view of world Englishes flexible in form and meaning, and adaptable to context and particularly to users' deployment of other languages in their repertoire. These varieties are anchored by function in context, and by the identities conferred on participants.

\section{REFERENCES}

Chew, Phyllis Ghim-Lian. 2006. Language use and religious practice: The case of Singapore. In Omoniyi and Fishman, 213-234.

Crystal, David. 1965. Linguistics, language, and religion. London: Hawthorn Books.

Firth, John Rupert. 1937. The tongues of men. London: Watts \& Co.

Ferguson, Charles A. 1982. Religious factors in language spread. Language spread: Studies in diffusion and social change, ed. by Robert L. Cooper, 95-106. Bloomington, IN: Indiana University Press; Washington DC: Center for Applied Linguistics.

Joseph, John E. 2006. The shifting role of languages in Lebanese Christian and Muslim identities. In Omoniyi and Fishman, 165-79.

Pandharipande, Rajeshwari V. 2006. Ideology, authority, and language choice: Language of religion in South Asia. In Omoniyi and Fishman, 141-64.

Kamwangamalu, Nkonko M. 2006. Religion, social history, and language maintenance: African languages in postapartheid South Africa. In Omoniyi and Fishman, 86-96.

Omoniyi, Tope. 2006. Societal multilingualism and multifaithism: A sociology of language and religion perspective. In Omoniyi and Fishman, 121-40.

Omoniyi, Tope (ed.) 2010. The sociology of language and religion. Palgrave Macmillan.

Omoniyi, Tope, and Joshua A. Fishman (eds.) 2006. Explorations in the sociology of language and religion. Amsterdam: John Benjamins.

Wolf, Hans-Georg. 2006. Religion and traditional belief in West African English: A linguistic analysis. In Omoniyi and Fishman, 42-59.

(Received 1 May 2013) 